\title{
DIE VERHOUDING TUSSEN INDIKATIEF EN PARAKLESE IN DIE BRIEF AAN DIE EFESIëRS ।
}

\author{
G.J.C. Jordaan \\ Departement Nuwe Testament \\ Potchefstroomse Universiteit vir Christelike Hoër Onderwys \\ POTCHEFSTROOM
}

\begin{abstract}
THE RELATIONSHIP BETWEEN INDICATIVE AND PARACLESIS IN EPHESIANS

The letter of the apostle Paul to the Ephesians is divided into two main sections. The first section is Ephesians 1:3 - 3:21 and is presented by the apostle as a prayer $(1: 16 ; 3: 13,14)$; the second section is found in Ephesians 4:1-6:24 and is presented as a paraclesis (4:1).
\end{abstract}

The prayer in chapters 1 to 3 exhibits the characteristic features of a Jewish berakah and it is based on a central theme, which is found in the declaration of foith in 1:20-23. The proclamation of Jesus Christ as Head of the church and the cosmos, and the church as His body, proves to be the great indicative not only of the berakah prayer in chapters 1 to 3 , but also of the entine letter.

In chapters 4106 the apostle proceeds to paraclesis, evident from the words rapaxatw

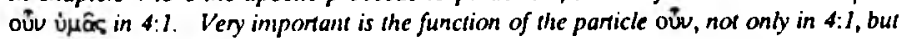
also in the rest of these last three chapters. The suggestion inherent in this small particle proves to be an imponant aspect of the whole letter, namely that the paraclesis is given as a result of the indicative. This is verified by a comparison between the rwo sections of the letter: quite a number of aspects which are mentioned in the indicasive section ane repeated in the paraclesis section, but then as "theory-brought-into practice", or as the paraclesis resulting from the indicative of the faith in Jesus Christ.

\section{INLEIDING: PROBLEEMSTEIIJNG EN DOEL}

Soos Paulus se ander briewe, vertoon sy brief aan die Efesiërs tipiese trekke van die Joods-Hellenistiese briefvorm (vgl. Van Roon, 1974:45-56; Du Toit, 1984:5-12). Die

${ }^{1}$ Hicrdic artikel is 'n verwerking van 'n referaat wat gedurende Julie 1989 tydens 'n Winterskoolkursus van die Fakulteit Teologic van die PU vir CHO onder leiding van prof. J.C. Coetzec aangebied is. Die artikel veronderstel dus dat die leser ook die artikel van C.J.H. Venter wat as inleidende referaat tydens dic kursus gedien het, gelees het (In die Skriflig 24(1) 1990 1-27). 
Efesiërbrief kan naamlik ingedeel word in 'n aanhef (1:1,2), 'n liggaam (1:3-6:20) en 'n slot (6:21-24). Die liggaam van hierdie brief is egter op 'n baie besondere wyse saamgestel.

Roberts (1984:139-140) dui aan dat die briefliggaam uit twee hoofdele bestaan, naamlik 1:3-3:21 en 4:1-6:20. Hierdie tweedeling word ook deur die meeste Nuwe-Testamentici en kommentatore gehandhaaf (bv. Kümmel, 1972:247, e.a. in die volgende paragraaf vermeld). So ' $n$ tweeledige briefliggaam kom meermale in die Pauliniese briewe voor (bv. Kolossense; 2 Tessalonisense) en is dus as sodanig nie vreemd nie. Wat by die Efesiërbrief wel nadere aandag vra, is die verhouding tussen die twee hoofdele. Die doel van hierdie studie is dan om bepaalde sake aan te toon wat lig kan werp op die verhouding tussen die eerste en tweede hoofdeel van die brief aan die Efesiërs en om daaruit enkele belangrike aspekte vir die hedendaagse prediking aan te dui.

Samehangend met die vraag na die verhouding tussen die twee hoofdele, is die vraag na die aard van elke hoofdeel. Oor hoe die aard van elk van die twee hoofdele getipeer moet word, is daar redelike verskil van mening onder Nuwe- Testamentici.

- Calvyn $(1979: 191,266)$ sê dat die eerste hoofdeel lofprysend is, terwyl die laaste hoofdeel geheel en al uit praktiese opdragte bestaan.

- Van Leeuwen (1921:91) beskou die eerste hoofdeel as belydend, en die tweede as vermanend. Ook Roberts (1984:140) noem die tweede deel vermanend.

- Abbott (1946:104), Grosheide (1960:6-7), Guthrie (1961:136) en Lopes (1986:43) is van mening dat die eerste briefdeel leerstellig van aard is en die tweede briefdeel prakties.

- Ook Berkelbach van der Sprenkel (1941:54) en Houlden (1977:237) beskou die eerste briefdeel as dogmaties van aard, maar die tweede deel beskou hulle as eties.

- Fischer (1973:13) tipeer die eerste deel as liturgies en die tweede deel as paraneties (so ook Kümmel, 1972:247).

- Van Roon (1976:74) stem met Fischer en Kümmel saam oor die paranetiese karakter van die tweede deel, maar die eerste deel tipeer hy as 'n gebed bestaande uit 'n eulogie, danksegging en voorbidding.

Dit is dus duidelik dat daar meningsverskil bestaan oor die presiese aard en karakter van die twee hoofdele van die brief. Hoewel hierdie studie nie op die bepaling van die aard en karakter van die brief as sodanig toegespits is nie, is dit tog vir die doel van die studie noodsaaklik om 'n definitiewe standpunt oor hierdie aangeleentheid in te neem. 


\section{DIE EERSTE HOOFDEEL VAN DIE BRIEF: EFESIēRS 1:3-3:21}

Roberts verwerp die opvatting dat die eerste briefdeel leerstellig van aard is (1984:139). Dat daar wel belydenisuitsprake in 1:3 - 3:21 voorkom, is wel duidelik, en daarvan het Roberts ook 'n deeglike studie gemaak (1988). Tog gee hierdie belydenisuitsprake nie aan die eerste briefdeel in sy geheel 'n leerstellige karakter nie. Veel eerder dra die eerste briefdeel in sy geheel die karakter van gebed. Myns insiens is die gebedskarakter van hierdie briefdeel oortuigend deur Roberts (1975:20; 1984:139$141 ; 1986: 191)$ aangetoon. Sonder om hierdie aangeleentheid dus weer van voor af te beredeneer, word in hierdie studie uitgegaan van die gebedskarakter van Efesiërs 1:33:21. Dit is egter nodig om na te gaan hoe hierdie eerste deel met sy gebedskarakter saamgestel is ten einde die verhouding daarvan tot die tweede hoofdeel te bestudeer.

\section{$2.1 \quad$ Kenmerke van 'n gebed}

Wanneer gesé word dat hierdie briefdeel 'n gebedskarakter vertoon, word nie daarmee bedoel dat die briefdeel in sy geheel 'n gebed is nie. Wat wel waar is, is dat dit in die vorm van 'n gebed geskryf is. Die briefdeel bevat naamlik elemente wat ook in die Joodse berakoth voorkom (vgl. Van Roon, 1976:15 vv.; Roberts 1984:139; 1988:191192). Gewoonlik het die Joodse berakoth bestaan uit 'n lofprysing gevolg deur die rede vir die lofprysing. Daarom word dit ook lofprysende gebede genoem. Dikwels is daar op die lofprysing uitgebrei deur ander elemente daaraan toe te voeg, byvoorbeeld voorbidding, skuldbelydenis en geloofsbelydenis. So 'n uitgebreide berakah-gebed is gewoonlik weer met lofprysing afgesluit (vgl. Roberts 1984:139). Die eerste deel van die Efesiërbrief is dan gestruktureer in die vorm van so 'n uitgebreicie berakah-gebed, en kan soos volg ingedeel word:

1:3 Lofprysing van God;

1:3-14 Rede vir die lofprysing: die verlossingsdade van God in Christus;

1:15-20 Voorbidding vir die lesers;

1:20-23 Geloofsbelydenis: Christus is die Hoof van die kerk;

2:1-22 Uiteensetting van die geloofsbelydenis: die eenheid

3:1-19 Voorbidding; van die kerk in Christus;

3:20-31 Lofprysing.

In 'n uitgebreide berakah-gebed het die lofprysing aan die begin gewoonlik by die lofprysing aan die einde aangesluit en is dit dikwels chiasties daarteenoor gerangskik. So 'n chiastiese gebedsrangskikking word ook in Efesiërs 1:3 - 3:21 aangetref, en dan wel in die A-B-C-B-A-patroon van die palindroom (vgl. Roberts, 1984:140; De Klerk, 1988:43): 


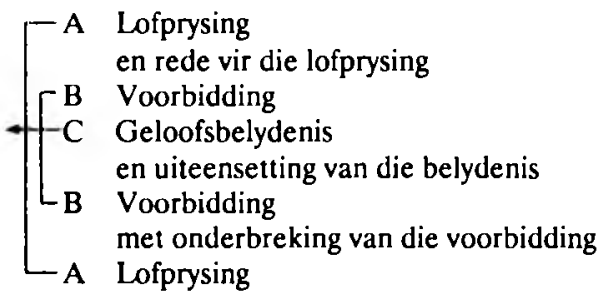

Die wentelpunt van die palindroom vorm gewoonlik die sentrale aspek van die hele struktuur. Die wentelpunt in hierdie verse is die geloofsbelydenis van 1:20-23. Efesiërs 1:3-3:21 is dus 'n gebed op die patroon van 'n Joodse berakah en so gerangskik dat dit om 'n sentrale geloofsbelydenis saamtrek.

Dat die sentrale geloofsbelydenis wel in 1:20-23 voorkom, word deur Meyer (1977:2426) gestel. Roberts $(1986: 199 ; 1988: 87-88)$ is van mening dat die sentrale geloofsbelydenis eers in 1:22-23 voorkom. Na sy oordeel maak 1:20-21 eintlik nog deel van die voorafgaande voorbidding uit. Hy gee toe dat 1:20-21 wel belydenisstof bevat, maar ken daaraan 'n oorgangsfunksie toe, in dié sin dat dit sterk terugverwys na die voorafgaande, maar ook aanduidings bevat van motiewe wat vorentoe in die brief 'n rol speel. ' $n$ Belangrike rede waarom hy 1:20-21 as deel van die voorafgaande voorbidding beskou, is die feit dat dit (as ' $n$ relatiewe bysin) sintakties ' $n$ inbedding by die vorige verse is en dus streng gesproke daarmee saam gelees moet word (Roberts, 1988:87-88). Tog is ek van oordeel dat die werklike geloofsbelydenis reeds by 1:20 begin en tot by 1:23 strek. Die redes hiervoor is die volgende:

1. Die feit dat vers 20 sintakties by die voorafgaande sin ingebed is, beteken nie dat dit noodwendig ook inhoudelik daarby ingebed is nie. Trouens, die Griekse betreklike voornaamwoord kan (ook in die Pauliniese briewe) 'n bysin inlei wat in betekenis gelykwaardig aan 'n selfstandige hoofsin is. ${ }^{2}$ Dit is dus heeltemal moontlik dat vers 20 inhoudelik reeds die aanvang van die geloofsbelydenis uitmaak.

\footnotetext{
2 Blass \& Debrunner (1975:131) dui aan dat die relatief dos $\delta \dot{e}$ in die Nuwe Testament en die papiri, soos in Klassieke Grieks, die konnotasie dra van Maur hy/en hy ..., byvoorbeeld Markus 15:23.

Dat hierdie verskynsel nie net tot die nominatief beperk is nie, is duidelik wanneer die vertaling van relatiewe voornaamwoorde in die Bybelvertaling van 1983 nagegaan word. In die eerste hoofstuk van Efesiers kom daar ses relatiewe voornaamwoorde voor (vv. 7, 8, 11, 13, 14, 20). In vier van die ses gevalle is die relatiewe voornaamwoord in die vertaling weergegee as die begin van 'n nuwe sin.
} 
2. Soos wat later in hierdie artikel aangedui word, bevat 1:20-21 saam met 1:22-23 bepaalde belydenismotiewe wat so grondliggend vir die res van die brief is, dat dit myns insiens beter is om 1:20-21 as deel van die sentrale geloofsbelydenis te beskou.

\subsubsection{Die geloofsbelydenis ten grondslag van die gebed}

Hierbo is aangedui dat die geloofsbelydenis van 1:20-23 die strukturele sentrum van die berakah-gebed in 1:3-3:21 is. Die sentrale plek van hierdie geloofsbelydenis is egter veel meer as bloot struktureel: dit vorm ook die gedagtesentrum van die gebed. Die indikatief van die Hoofskap van Jesus Christus wat in 1:20-23 bely word, is ook die gedagtegrondslag waarop die gebed in sy geheel berus.

\subsubsection{Gedagtesentrum en gedagtelyne van die geloofsbelydenis}

In die meegaande gedetailleerde ontleding (vgl. die skematiese uiteensetting 1) word aangetoon hoedat die geloofsbelydenis van 1:20-23 inderdaad die sentrum van die hele briefdeel vorm. Daarin word ook aangetoon dat 1:3-4:21 verskeie gedagtelyne bevat wat van die begin van die briefdeel tot aan die einde daarvan deurloop. Dit blyk egter dat hierdie gedagtelyne almal in die sentrale geloofsbelydenis van 1:20-23 saamtrek. Die plek van die geloofsbelydenis sou ook vergelyk kon word met die dun nekkie van 'n uurglas waardeur die sand van die boonste na die onderste deel vloei: die gedagtelyne van die eerste helfte van die palindroom word deur die geloofsbelydenis van 1:20-23 na die tweede helfte van die palindroom oorgedra. Die struktuur sou dus soos volg voorgestel kon word:

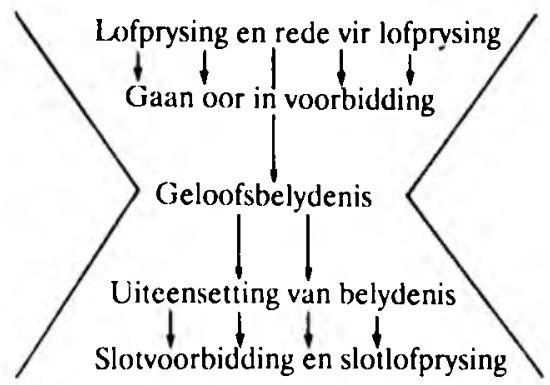

In die rede vir die lofprysing voor die geloofsbelydenis word die beginpunt van verskeie gedagtelyne aangetref wat in die geloofsbelydenis self ontbreek, maar wat 


\section{SKEMATIESE UITEENSETTING I}

'n Verkortc Icks van Ef I tot 3 word hicromeler in 6 kolomme verdecl. In clke kolem menel dic leks van bo nil onder gelecs word.

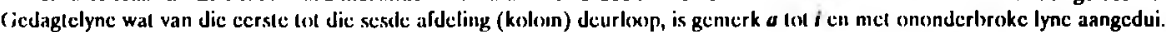

\section{REDE VIR DIE LOFPR YSING; (1:4-14)}

VOORIBIDDING; (1:14-21)i)

GELOOFSBELYDENIS (1:206-23)

:4 Dic: Yader helons vilycikics o om heilig en sonder gebrek te wees $b$

$.5 \mathrm{om}$ ons as sy kinders aan Ic necm

:6 tor lof vd hecrlikh v sy genade

$: 7$ In Xius hel Hy verlossing bowcrk dic vergifnis vin ons nisdade na dic rykdom van sy gcuinde :17 Dat dic Vader vd hecrlikheid sal gee: V dic Geses dic Secs $b$

8 bewys in wysheid en versland $d \longrightarrow$ wal dic hoxip van sy rocping 9 deur openb.making $\mathrm{v}$ sy verlorge wil $e \rightarrow$ cn dic rykdom van sy hecrlikheid $-c$

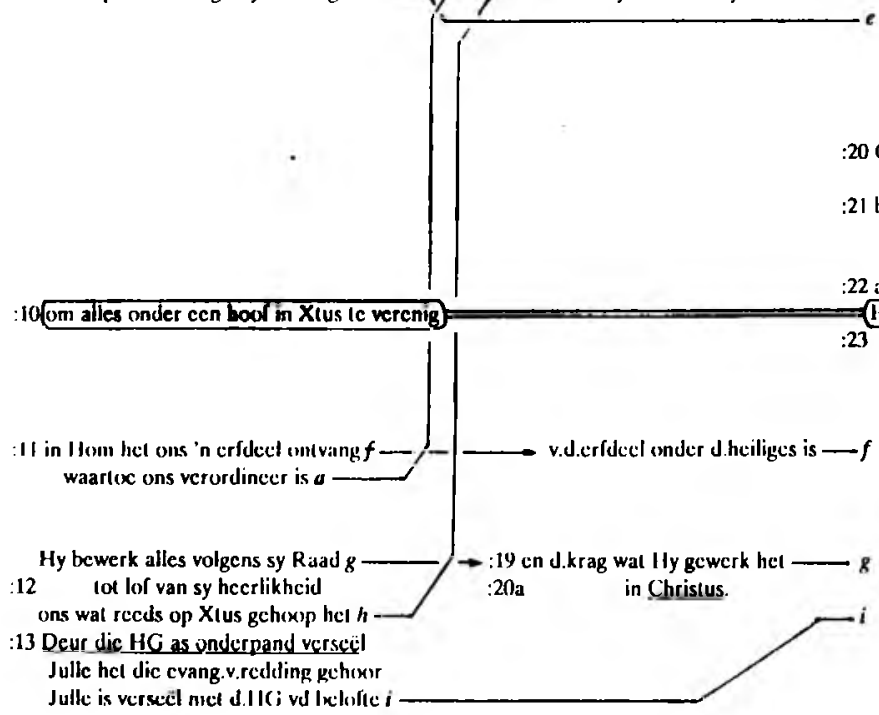

:14 Dic HG; is inderpand v.ons erfueel om ons te verlos Iox lof v.sy hecrlikhcid. 


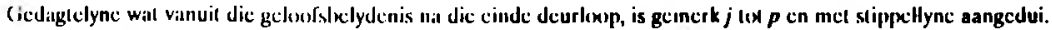

Gedagtelyne wal slegs van cen afdeling (kolim) na dic volgende corloop, is gemerk $q$ tox $u$ en mel onderbroke lyne aangedui.

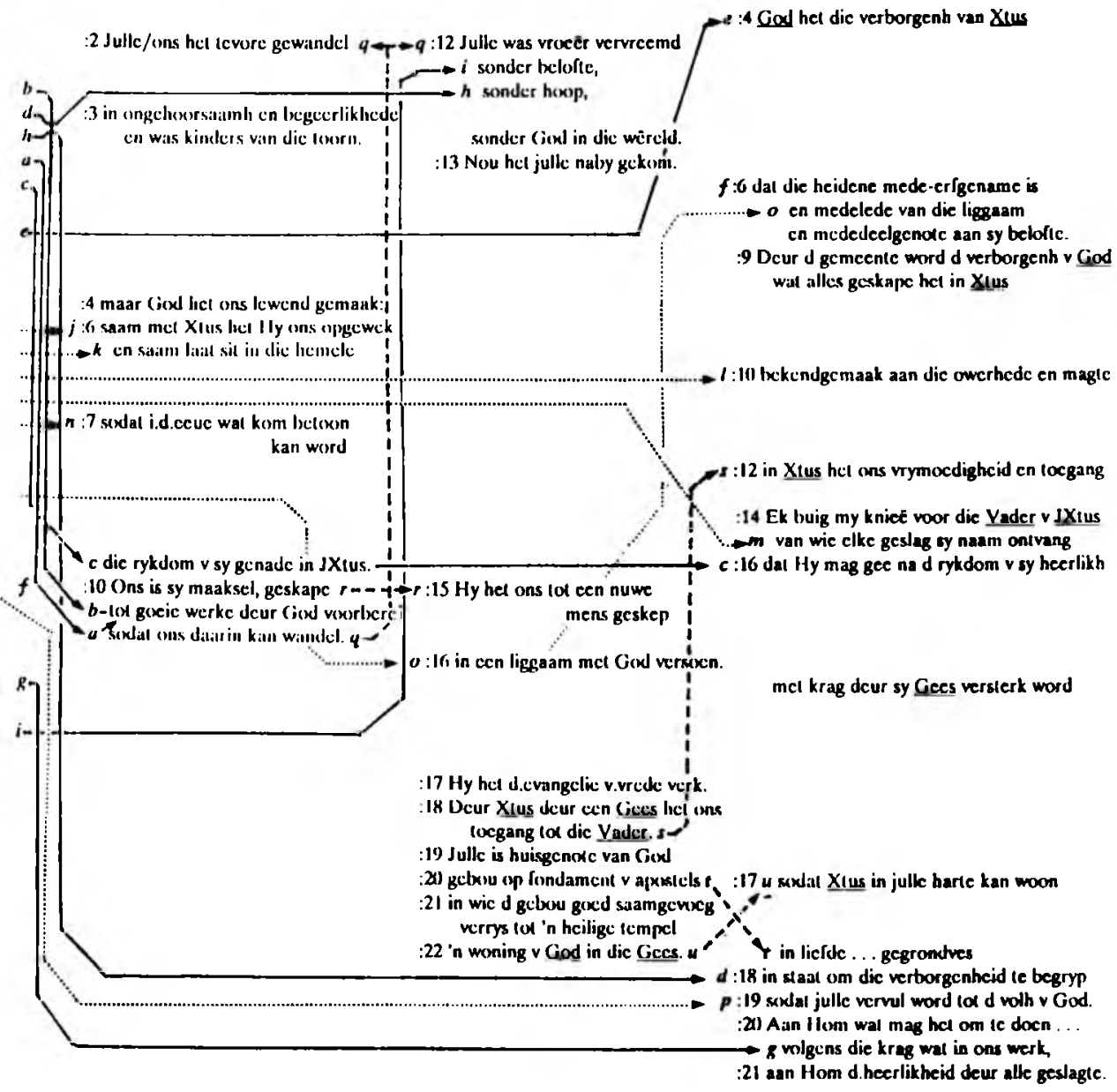


weer in die daaropvolgende gedeeltes na vore te tree. Die sentrale motiewe wat so onderbreek en voortgesit word, is die volgende:

a. Die uitverkiesing (1:4), verordinering (1:11), roeping (1:18) - en die voorbereiding van goeie werke (2:10).

b. Heiligheid (1:4) - goeie werke (2:10) en heilige tempel (2:21).

c. Rykdom van Gods genade (1:7), die rykdom van sy heerlikheid (1:18) die rykdom van sy genade (2:7) en die rykdom van sy heerlikheid (3:16). Dit is ' $n$ parallelisme op die A-B-A-B-patroon.

d. Wysheid en verstand (1:8), wysheid en openbaring van kennis (1:17) - in staat om die verborgenheid te begryp (3:18).

e. Openbaring van sy verborge wil (1:9) - die verborgenheid van Christus geopenbaar $(3: 4,5,9,10)$.

f. In Hom 'n erfdeel ontvang (1:11), die erfdeel onder die heiliges (1:18) die heidene is mede-erfgename $(3: 6)$.

g. Hy bewerk ('́vep€y€îu) alles volgens sy raad (1:11), die krag wat $\mathrm{Hy}$ in Christus gewerk (évep€y€îv) het $(1: 19)$ - die krag wat in ons werk (évepyeîu) (3:20).

h. Ons het op Christus gehoop (1:12), die hoop van sy roeping (1:18) - julle was sonder hoop (2:12).

i. Die Heilige Gees van die belofte (1:13) - vreemdelinge t.a.v. die verbonde van die belofte $(2: 12)$, die heidene is mededeelgenote aan sy belofte $(3: 6)$.

Al die bostaande gedagtelyne word in 1:3-1:20 begin en word weer in 2:1-3:21 voortgesit. Die lyne word egter by die geloofsbelydenis $(1: 20-23)$ onderbreek. Slegs een gedagtelyn verbind die geloofsbelydenis met die voorafgaande, naamlik die gedagtelyn van die Hoofskap van Christus (1:10 en weer 1:22). Hierdie gedagtelyn vorm die sentrale motief van die brief: die Hoofskap van Christus oor die kerk, sy liggaam. Hierdie sentrale motief vorm dan as't ware die "dun punt van die uurglas" waardeur al die ander gedagtelyne van die eerste briefdeel vloei.

Uit die geloofsbelydenis as sentrum van die drie hoofstukke vioei weer nuwe gedagtelyne voort, wat ook in die daaropvolgende gedeeltes voortgesit word (vgl. ook Roberts, 1988:90-91 in hierdie verband). Die gedagtelyne is die volgende:

j. God het Christus uit die dode opgewek (1:20) - saam met Christus het God ons opgewek (2:6).

k. Hy het Hom laat sit aan sy regterhand in die hemele (1:20) - saam met Christus het Hy ook ons laat sit in die hemele (2:6).

1. Bo alle owerheid en mag en krag en heerskappy $(1: 21)$ - aan die owerhede en magte bekend maak (3:10).

m. En elke naam wat genoem word (1:21) - van wie elke geslag in die hemele en op die aarde sy naam ontvang (3:15).

n. In hierdie wêreld en ook in die toekomstige (1:21) - sodat in die eeue wat kom, betoon kan word (2:7). 
o. Die gemeente wat sy liggaam is (1:23) - in een liggaam met God versoen (2:16), medelede van die liggaam (3:6).

p. Die volheid van Hom wat alles in almal vervul $(1: 23)$ - vervul tot al die volheid van God (3:19).

Die beginpunt van die deurlopende gedagtelyne in die eerste drie hoofstukke word dus aangetref in die rede vir die lofprysing (1:3-14) en in die geloofsbelydenis (1:20-23). Die verloop van die gedagtelyne kan dan soos volg voorgestel word:

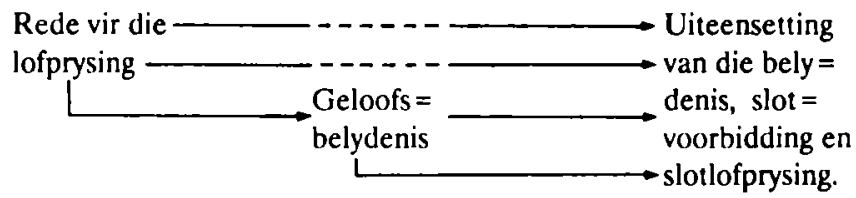

Daar is enkele kleiner gedagtelyne wat in die uiteensetting van die belydenis ontspring en dan na die slotvoorbidding en -lofprysing deurloop. Sulke gedagtelyne is die volgende:

q. Ons vroeëre lewenswandel (2:2) teenoor ons nuwe lewenswandel (2:10), wat aan 2:1-10 die struktuur van 'n ringkomposisie verleen.

r. Ons is sy maaksel, geskape $(2: 10)$, tot een nuwe mens geskep $(2: 15)$.

s. Deur Christus toegang tot die Vader (2:18), in Christus die vrymoedigheid en die toegang (3:12).

t. Gebou op die fondament ( $\theta \epsilon \mu \epsilon \lambda i(\omega)$ van die apostels en profete $(2: 20)$, in

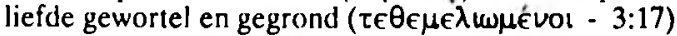

u. 'n Woning (katolkntiplov) van God in die Gees (2:22), dat Christus kan woon (katoikñoal) in julle harte (3:17).

\subsubsection{Gedagtesentrum en gedagtelyne as indikatief van die gebed}

In bovermelde gedagtelyne is die berakah van 1:3 - 3:21 gegrond. 'n Mens sou hierdie gedagtelyne ook die indikatief van die hele gebed kon noem. Daarmee word bedoel dat die heilsfeite van die Hoofskap van Jesus Christus, soos dit in die verskillende gedagtelyne voortgedra word, die belyde of verkondigde waarhede is waaruit die lofprysing en die voorbidding van die berakah-gebed voortspruit (vgl. Du Plessis, 1962:58$62)$.

Uit die beskrywing van die gedagtelyne hierbo is dit duidelik dat die indikatiewe waarhede wat daarin verkondig word, weliswaar leerstellig van aard is. Hoewel die hele eerste briefdeel 'n gebedskarakier het, is dit dus gegrond op 'n gedagtesentrum en -lyne wat leerstellig van aard is. Die leerstellige aard van die gedagtesentrum en -lyne het verskeie Nuwe-Testamentici daartoe gelei om aan die hele briefdeel 'n dogmatiese karakter toe te ken (vgl. die inleidende paragrawe van hierdie artikel). Teenoor sodanige gevolgtrekking moet gestel word dat slegs die onderliggende gedagtesentrum en -lyne 
van hierdie briefdeel leerstellig van aard is. Formeel vertoon die hele briefdeel die eienskappe van 'n berakah-gebed.

\subsubsection{Die trinitariese motief in die indikatief}

Roberts (1975:18) en Floor (1982:17vv.) wys op 'n baie belangrike motief waarbinne die indikatief van die Efesiërbrief verkondig word, naamlik die trinitariese motief. Die Efesiërbrief verkondig immers die geestelike seëninge wat die Vader in Christus deur die Heilige Gees in die lewens van sy uitverkorenes bewerk (Floor, 1982:78). In die uiteensetting van die gedagtestruktuur van hoofstukke 1 tot 3 (skematiese uiteensetting 1 ) is die trinitariese inkleding van die indikatief duidelik:

* In die rede vir die lofprysing (1:4-14):

- Die Vader het ons uitverkies (1:4-6)

- In Christus het Hy ons verlossing bewerk (1:7-12)

- Deur die Heilige Gees as Onderpand is ons verseël (1:13-14).

Let op hoe elke afdeling afsluit met die refrein: "Tot lof van sy heerlikheid!"

* In die voorbidding (1:15-20a):

- Dat die Vader van die heerlikheid sal gee (1:17)

- die Gees van wysheid. .. (1:17)

- die krag wat Hy gewerk het in Christus (1:20a).

* Uiteensetting van die belydenis (2:11-22):

- Deur Christus het ons toegang deur een Gees tot die Vader (2:18).

- Huisgenote van God (die Vader) (2:19)

- terwyl Jesus Christus self die hoeksteen is (2:20)

- 'n woning van God in die Gees (2:22).

- Slotvoorbidding (3:1-19):

In die onderbreking van die voorbidding (3:2-13):

- Die verborgenheid van Christus (3:4)

- geopenbaar deur die Gees (3:5)

- volgens die gawe van die genade van God $(3 ; 2,7)$.

In die voorbidding self:

- Ek buig my knieë voor die Vader

- van onse Here Jesus Christus (3:14)

- dat Hy mag gee om met krag versterk te word deur sy Gees (3:16).

- Slotlofprysing $(3: 20,21)$ :

- Aan Hom wat mag het om te doen ver bo alles wat ons bid ( = die Vader),

- volgens die krag wat in ons werk ( = die Heilige Gees,vgl. 3:16),

- aan Hom die heerlikheid in die gemeente in Christus Jesus. 
Samevattend kan gesê word dat die indikatief in Efesièrs 1:3-3:21 in 'n hele aantal gedagtelyne gestel word, wat in die sentrale motief van die Hoofskap van Christus saamtrek, en wat binne 'n trinitariese raamwerk aangebied word.

\section{DIE TWEEDE HOOFDEEL VAN DIE BRIEF: EFESIēRS 4:1-6:20}

\subsection{Die tweede hoofdeel het 'n parakletiese aard}

In die inleiding van hierdie artikel is reeds aangetoon dat verskeie Nuwe-Testamentici die tweede briefdeel verskillend tipeer: prakties, vermanend, eties of paraneties. Hoewel hierdie tiperings in der waarheid weinig van mekaar verskil, is daar ' $\mathrm{n}$ term waarmee die briefdeel selfs nog beter getipeer kan word - die woord paraklese. Hierdie woord is afgelei uit die woord waarmee die skrywer self die tweede briefdeel begin,

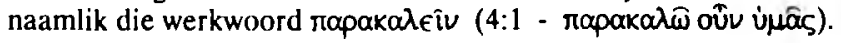

Die woord ropaka $\omega \omega$ word uitgelig omdat dit in der waarheid die wendingspunt in die brief verteenwoordig. Doty (1973:39) toon aan dat die woord rapaka Hellenistiese briewe as aanduiding van 'n wendingspunt in die brief voorkom. Tapakahô lei dan die vermanende deel van die brief in, ook genoem die paranetiese deel van die brief (Kümmel, 1972:247; Fischer, 1973:13). Met die woord rapaka word egter aangedui dat die skrywer meer as 'n paranese gaan aanbied. In plaas van 'n blote lys van moralistiese moets en moenies, gaan die skrywer ' $n$ paraklese aan sy lesers gee, dit wil sế 'n vermaning met besondere intimiteit en vertroue in sy lesers (Doty, 1973:39).

Ook in die Nuwe Testament dui die woord rapaxalfî 'n vermaning van besondere intieme en persoonlike aard aan. Volgens Louw \& Nida $(1988: 409,425)$ word die woord rapaka入eiv gebruik binne die betekenisveld van 'n dringende versoek rig. Op grond van die intieme en persoonlike vertrouensband tussen die skrywer en sy lesers rig hy 'n dringende vermanende versoek tot hulle.

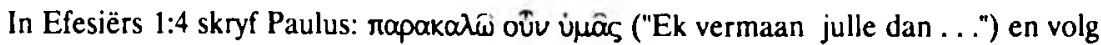
dit op met'n voorwerpsin wat die inhoud van die paraklese stel: " ... om te wandel waardig die roeping waarmee julle geroep is ...". Hy brei die voorwerpsin dan weer in verse 2 en 3 uit met verder bepalings. In hierdie geval is die paraklese 'n ermstige aandrang of 'n dringende versoek (Louw \& Nida, 1988:409) oor die bepaalde lewenswandel wat van die lesers verwag word.

Die paraklese van die brief hou egter nie by hierdie enkele aandrang/versoek in 4:1 op nie. Efesiërs 4:1 is in der waarheid die inleiding tot 'n uitgebreide stuk paraklese wat tot by 6:20 strek. En dan, in die briefslot (6:22), kom die woord rapakaltiu weer

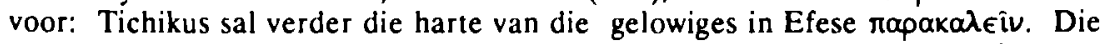

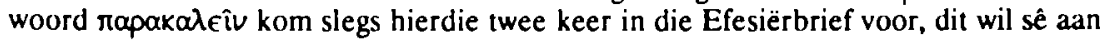
die begin en aan die einde van die tweede briefdeel - as't ware by wyse van ringkom- 


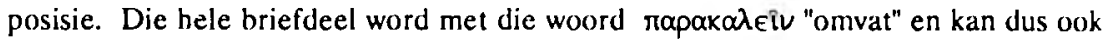
omvattend getipeer word as paraklese.

Die betekenisveld waarbinne Paulus die woord $\pi \alpha \rho \alpha k \alpha \lambda \in i v$ in hierdie briefdeel aanwend, dui aan wat die aard van die paraklese is wat hy tot sy lesers rig. In 4:1 rig hy 'n dringende versoek tot hulle (Louw \& Nida, 1988:409,425), 'n versoek wat vermanend van aard is. In 6:22 skryf hy dat hy ook Tichikus na hulle toe stuur om

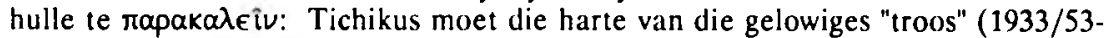
vertaling) sodat hy "die kommer in hulle gemoed kan wegneem" (1983-vertaling).

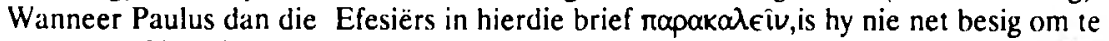
vermaan of 'n dringende versoek tot hulle te rig nie. Hy is ook besig om die Efesiërs onder hulle omstandighede te vertroos deur hulle te bemoedig.

Hierdie tweede deel van die Efesiërbrief kan dus getipeer word as bemoedigende vertroosting of vertroostende bemoediging, of, in aansluiting by die werkwoord rapakalєiv, getipeer word as paraklese.

\subsection{Die samehang van die paraklese in Efesiërs 4:1-6:20}

Doty (1973:59) toon aan dat daar op verskeie plekke in die Nuwe-Testamentiese geskrifte gedeeltes voorkom wat 'n "kategetiese patroon" vertoon. Hierdie kategetiese stof vorm, aldus Doty, deel van 'n vroeg-Christelike heiligheidskode, wat in navolging van die heiligheidskode van die Tora onstaan het. Die inhoud van die Nuwe-Testamentiese heiligheidskodes was dan om bepaalde bose werke af te lè en om die nuwe Christelike lewenstyl op te neem.

In die paraklese-gedeelte van die Efesiërbrief is daar ook gedeeltes wat in so 'n "kategetiese" styl aangebied word, naamlik 4:22-5:21 (Doty,1973:59; Aune, 1987:195). Bultmann en ook Percy (aangehaal deur Van Roon, 1974:411) beskou die kategetiese stof in hierdie brief as vroeg-Christelike materiaal wat nie oorspronklik van Paulus kom nie en verklaar daarom 4:1-6:20 as on-Paulinies. Van Roon wys egter daarop dat "kategismusagtige" gedeeltes in 4:1-6:20 nie die produk van 'n vroeg-Christelike "kategismus" is nie, maar dat dit wel 'n aantal fundamentele paranetiese formuleringe bevat wat oor en oor in Paulus se briewe voorkom. Die "kategismusagtige" gedeeltes in 4:1 6:20 is dus na sy oordeel eg Paulinies, maar bestaan uit 'n onsamehangende sameflansing van verskillende dringende versoeke en vermaninge.

Dat bepaalde gedeeltes uit hierdie tweede briefdeel inderdaad onderrigtend van aard is en ook in ander briewe van Paulus voorkom, is waar. Die lyste van sondes in 4:2532 en 5:3-5 toon duidelike oorkomste met ander sondelyste in die Pauliniese briewe. 'n Duidelike ooreenkoms word gevind in die "tweelingsuster" van die Efesiërbrief, naamlik die brief aan die Kolossense. 'n Vergelyking van die twee briewe toon talle ooreenkomste in struktuur en bewoording - selfs ten opsigte van die sentrale motief. Ook die sondelyste van Efesiërs 4 en 5 lyk feitlik dieselfde as dié in Kolossense 3:1-17. 
Die sondelyste as sodanig sou dus wel as "kategismusagtig" getipeer kon word, maar dit beteken nie dat dit onsamehangend binne die konteks van die Efesiërbrief neergeskryf is nie. Roberts (1983) toon aan dat daar wel 'n definitiewe samehang in die tweede hoofdeel van die brief bestaan.

In die skematiese uiteensetting van die gedagtestruktuur van 4:1-6:20 (vgl. skematiese uiteensetting 2 op p.62) word gepoog om aan te toon hoedat die verskillende parakletiese uitsprake inderdaad onderling aan mekaar verbonde is (skematiese uiteensetting 2). Uit die uiteensetting is dit duidelik dat die parakletiese stof in 4:1-6:20 nie ' $n$ onsamehangende samevoeging van "kategetiese" stof is nie, maar inderdaad 'n betekenisvolle gedagte-opbou vertoon. In hierdie hoofstukke word die breë paraklese van wandel waardig die roeping waarmee julle geroep is as't ware in konsentriese sirkels al nader en nader gepresiseer, telkens met praktiese toepassings van die algemene stellings. Let veral op

- die herhaalde voorkoms van die partikel oûv as struktuurmerker;

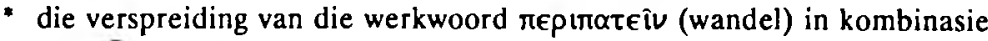
met ơv, as 'n verdere struktuurmerker.

\subsubsection{Indikatief te midde van die paraklese in Efesiërs 4:1-6:20}

In die skematiese uiteensetting 2 (vgl. p.62) word aangetoon dat 4:4-16, hoewel dit binne die raamwerk van paraklese voorkom, self nie parakleties van aard is nie. Efesiërs 4:4-16 dien as 'n motivering vir die voorafgaande oproep om die eenheid van die Gees te bewaar. Die motivering geskied deur 'n leerstellige uiteensetting in 4:416 oor die eenheid van die kerk. Die eenheid word leerstellig soos volg gemotiveer:
4:4-6
- Die eenheid van die kerk is daarin geleë dat God aan al die gelowiges gemeenskaplike gawes gee.
4:7-10 - Die eenheid van die kerk is daarin geleê dat die gelowiges mekaar nodig het. Christus het immers nie dieselfde gawes aan almal gegee nie.
4:11-16 - Die eenheid van die kerk word gedien deur die verskillende ampte wat Christus in sy kerk gegee het,
4:16 - eindig by die beeld van die kerk as liggaam, in ' $n$ ring = komposisie aansluitend by die "een liggaam" van v. 4 .

Verse 4-16 bevat duidelik geen paraklese nie, maar stel die grond vir die paraklese in v. 3: die verkondiging van die eenheid van die kerk, op grond waarvan Paulus sy lesers daartoe oproep om die eenheid te bewaar. Verse $4-16$ is dus die indikatief waarop die paraklese van v. 3 gegrond is. 


\section{SKEMATIESE UITEENSETTING 2}

A

4:4-16

4:17-24

B

4:25-32

$5: 1-2$

C

$5: 8-14$

D

5:15-21

$5: 22 \cdot 6: 9$

E

6:10-20

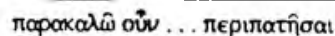

Dic algemene inleidende paraklesc wat die grondslag vir alle verdere paraklese stel:

Wandel waardig die roeping waarmee julle geroep is! (met die liefde, vrede en eenheid van die Gees)

(mel die licfde,

Dic indikatief waarin die paraklese van A gegrond is:
Die kerk is een liggaam onder Christus as Hoof.

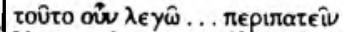

Voortsetting en terselfdertyd nadere presisering van dic algemene paraklese in A. In beginsel beteken paraklese A:

Die aflegging van die ou mens en die opstanding van die nuwe mens wat na God geskape is.

$\Delta \omega \ldots$

Praktiese illustrasic van paraklese $B$ :

Die affegging van dic ou mens = aflegging van bepaalde woorde, gesindhede en dade (sondelys); en die opstanding van die nuwe mens = opneem van ander woorde, gesindhede en dade (àl $\dot{\alpha})$.

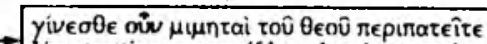

Voortsetting en terselfdertyd nadere presisering van dic algemenc paraklese in $\mathrm{B}$ :

Met die nuwe na-God-geskape mens beklec, moet ons novolgers van God wees, soos geliefde kinders.

Praktiese illustrasic van paraklesc C :

'n lys van sondige praktyke waaraan nic deelgeneem mag word (ở $v, v, 7)$ nic.

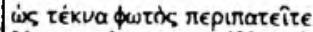

Voortselting en terselfdertyd nadere presisering van dic algemene paraklese in $\mathrm{C}$ :

Wie God navolg, soos geliefde kinders, is nie meer duisternis nie maar wandel soos kinders van die lig.

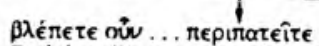

Prakticse illustrasie van Paraklese D:

Om soos kinders van die lig te wandel beteken

om in wysheid op te tree, nie dronk te word nie

... en aan mekaar onderdanig te wees.<smiles>[AlH2]</smiles>

As ' $n$ verdere uithouing van dic paraklese van onderlinge onderdanigheid volg die huistafels:

Vrou en man (5:22-33); Kinders en ouers (6:1-4);

Werknemers en werkgewers(6:5-9).

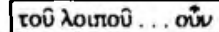

Ter afsluiting van die paraklese oor die waardige

lewenswandel van die gelowiges, word die lesers met die beeld van dic wapenrusting van (jod tot standvastigheid in die geloofstryd opgeroep. 
In die res van hoofstukke 4, 5 en 6 is daar nog kleiner gedeeltes wat nie werklik parakleties van aard is nie maar wat, soos $4: 4-16$, die indikatief stel waarop bepaalde gedeeltes van die paraklese gegrond is. Hiervan is die volgende duidelike voorbeelde (vgl. weer skematiese uiteensetting 1):

\section{4:25 "... want ons is mekaar se lede"}

as grond vir die paraklese: "Spreek die waarheid elkeen met sy naaste."

4:30 ". . . die Heilige Gees deur wie julle verseël is tot die dag van verlossing" as grond vir: "Bedroef nie die Heilige Gees van God nie."

4:32 "... soos God ook in Christus julle vergewe het" as grond vir: "Vergeef mekaar".

5:2 ". . . soos Christus ons ook liefgehad het en Hom vir ons oorgegee het as 'n gawe en offer aan God tot ' $n$ lieflike geur" as grond vir: "Wandel in liefde."

5:22 ". . soos aan die Here, want die man is die hoof van die vrou, soos Christus ook Hoof is van die gemeente; en Hy is die Verlosser van die liggaam" as grond vir: "Vroue, wees aan julle eie mans onderdanig."

5:25 "... soos Christus ook die gemeente liefgehad het en Homself daarvoor oorgegee het ... dat dit heilig en sonder gebrek sou wees" en

5:29 ". . . soos die Here die gemeente voed en koester, ons is lede van sy liggaam" as grond vir: "Manne, julle moet julle eie vroue liefhê."

Dit blyk dus dat daar verskeie plekke in die geheelopset van 4:1-6:20 is waar daar nie opdragte of vermaninge gegee word nie, maar waar die gronde vir die opdragte en/of vermanings voorsien word. Die gronde bestaan telkens uit die indikatief van dit wat God in Christus aan sy kerk geskenk het.

\section{DIE VERHOUDING TUSSEN INDIKATIEF EN PARAKLESE IN DIE EFESIëRBRIEF}

\subsection{Die verhouding van die tweede briefdeel tot die indikatief}

Hierbo is reeds aangetoon dat daar in die tweede deel van die Efesiërbrief sowel parakletiese as indikatiewe elemente aanwesig is, en dat die indikatief in die briefdeel telkens as die grond van die paraklese gestel word. In die tweede briefdeel bestaan daar dus 'n noue band tussen indikatief en paraklese. Dieselfde noue band tussen indikatief en paraklese is sigbaar wanneer die eerste en die tweede briefdele met mekaar vergelyk word. Die paraklese van hoofstukke 4 tot 6 is ten nouste verbonde aan die indikatief van hoofstukke 1 tot 3 . Hierdie noue verbintenis blyk uit:

- Sekere herhalings van die eerste briefdeel in die tweede briefdeel.

- Die verspreiding van die partikel oûv. 


\subsubsection{Herhalings van die eerste briefdeel in die tweede briefdeel}

Hierbo is reeds gewys op die groot gedeeltes indikatief wat in Efesiërs 4:4-16 aangetref word, as't ware as 'n groot "eiland" van indikatief in die paraklese-gedeelte. Ook is daarop gewys dat hierdie groot indikatief die eenheid van die kerk verkondig, en klimakties opbou tot by die Hoofskap van Christus oor die kerk, sy liggaam $(4: 15,16)$. Hiermee word duidelik teruggewys na die sentrale motief van die indikatief in die eerste briefdeel: die Hoofskap van Christus oor sy liggaam, die kerk (vgl. 2.1.1.1 hierbo). Die sentrale motief van die indikatief loop dus nie in die eerste briefdeel ten einde nie, maar word in die tweede briefdeel voortgesit.

Daar is ook ander belangrike gedagtelyne wat hierdie perikoop aan die eerste briefdeel verbind. Veral word die beeld van die gebou in Efesiërs 2:19-22 in 4:4-16 voortgesit, maar dit word oorgedra op die beeld van die liggaam. Die volgende tabel vergelyk die woordooreenkomste tussen die eerste briefdeel en 4:4-16 (vgl. ook skematiese uiteensetting 1):

Eerste briefdeel

1:18 die hoop van sy roeping

1:22 as Hoof van die gemeente

2:16 Albei in een liggaam

2:18 toegang deur een Gees

2:21 die gebou goed saamgevoeg

2:22 julle saam opgebou word

\section{Efesiërs 4}

4.4 een hoop van julle roeping 4:15 die Hoof, naamlik Christus

4:4 Dit is een liggaam en een Gees

4:16 die liggaam goed gevoeg

4:12 opbouing van die liggaam

Die ooreenkoms met die eerste briefdeel is nie beperk tot die indikatief in 4:4-16 nie. Ook die ander indikatief-gedeeltes in die tweede briefdeel toon 'n baie duidelike ooreenkoms met die gedagtelyne van die indikatief in die eerste briefdeel. In der waarheid is die tweede reeks indikatiewe in vele opsigte 'n blote terugverwysing na die indikatiewe wat reeds in die eerste briefdeel gestel is. Die volgende ooreenkomste is maklik waarneembaar:

\section{Eerste briefdeel}

1:4 "uitverkies ... om heilig en sonder gebrek voor Hom in liefde te wees."

1:6 "sy genade waarmee Hy ons

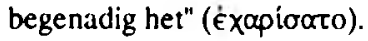

\section{Tweede briefdeel}

5:27 "sodat die gemeente heilig en sonder gebrek sou wees."

4:32 "soos God ook in Christus julle vergewe het"(éxapioøto). 


\section{Eerste briefdeel}

1:13 "verseël met die Heilige Gees van die belofte."

1:18 "die hoop van sy roeping"

1:22,23 "Christus is die Hoof, die kerk sy liggaam."

2:21 "goed saamgevoeg"

3:6 "medelede van die liggaam"

2:3 "vroeër gewandel in die begeerlikhede van die vlees en kinders van die toorn."

2:10 "sy maaksel, geskape in Christus Jesus . ."

2:12 "vervreemd van die burger $=$ skap van Israel, sonder God."
Tweede briefdeel

3:30 "die Heilige Gees deur wie julle verseël is."

4:4 "hoop van julle roeping"

5:23 "soos Christus ook Hoof is van die gemeente"

4:4,15,16 "uit die Hoof, naamlik Christus is die liggaam goed saamgevoeg."

5:30 "lede van sy liggaam".

4:25 "ons is mekaar se lede"

4:22 "wat die vorige lewenswandel betref, deur die begeerlikhede van die verleiding ten gronde."

4:24 "die nuwe mens wat na God geskape is."

4:17 "vervreemd van die lewe van God."

Dit is dus asof die primêre indikatief-gedeelte van die brief (1:3-14, 1:20-23; 2:1-22) op verskeie plekke in die parakletiese briefdeel 'n weerklank vind. Dieselfde indikatief wat vroeër gestel is, word weer gestel, maar nou direk aan die paraklese verbind. Anders gestel: die parakletiese deel van die brief word via bepaalde herhalings "terug"begrond in die eerste (indikatiewe) briefdeel.

\subsubsection{Verspreiding van die partikel oûv}

Dit is opvallend dat die partikel oûv slegs in die parakletieșe deel van die brief voorkom. In die eerste drie hoofstukke kom oûv slegs een keer voor, en dit in die kombinasie apa oũv (2:19). In die parakletiese briefdeel kom die partikel oûv (op sigself) nie minder nie as ses keer voor, en telkens op belangrike plekke. Alreeds in 4:1 neem oưv 'n belangrike plek in, direk langs die werkwoord rapaxatw - die tiperende werkwoord van die hele laaste briefdeel. Die funksie van ouv is uiteraard konkluderend. Met oûv in 4:1 word as't ware gesê: die paraklese in die tweede briefdeel 
is die konklusie van dit wat voorafgaan, van die indikatief van die eerste briefdeel. Ten einde hierdie verband te bevestig, word die oûv telkens by die voortsetting van die algemene paraklese (vgl. 3.2 hierbo) herhaal.

Met die opvallende herhaling van oûv in die parakletiese deel van die brief word duidelik aangetoon dat die paraklese in die Efesiërbrief telkens as 'n konklusie vanuit die indikatief gestel word. Die hele paraklese van die Efesiërbrief word in der waarheid deur die partikel oûv konkluderend aan die indikatief verbind.

Die indikatief is dus nie bloot funksioneel in die Efesiërbrief ingesluit ten einde 'n begronding vir die paraklese voorsien nie. Die indikatief vorm 'n selfstandige deel van die brief, met die paraklese wat organies as konklusie daaruit voortvloei. Aan die ander kant is die paraklese op sy beurt nie ' $n$ blote anhangsel by die indikatief nie. Die paraklese is die onafwendbare vrug van die indikatief. Op hierdie wyse word daar in die Efesiërbrief 'n noukeurige ewewig tussen indikatief en paraklese gehandhaaf: die een is die wortel, die ander die vrug; albei is ewe onmisbaar.

\subsection{Die verhouding van die eerste briefdeel tot die paraklese}

Die eerste briefdeel stel die indikatief, terwyl die tweede briefdeel daarop teruggryp en met paraklese daarop voortbou. Die eerste briefdeel bevat dus geen paraklese nie - altans nie eksplisiete paraklese nie. Implisiet is daar wel definitiewe paraklese in die eerste briefdeel teenwoordig. Ingebed in die eksplisiete indikatief word die paraklese implisiet aangetref. Die volgende dien as voorbeelde:

1:4 "God het ons in Christus uitverkies ... om heilig en sonder gebrek voor Hom in liefde te wees."

Implisiete paraklese: Wees heilig (vgl. 5:7), lê die sonde af (vgl. 4:22) en wandel in liefde (vgl. 5:2).

1:5 "God het ons voorbeskik om ons as sy kinders aan te neem ... " Implisiete paraklese: Tree op as kinders van God (vgl. 5:1 - wees dan navolgers van God soos geliefde kinders; en 5:8 - wandel soos kinders van die lig).

1:6 ".. tot lof van die heerlikheid van sy genade ..."

Implisiete paraklese: Loof die Naam van die Here (vgl. 5:19 sing en psalmsing in julle hart tot eer van die Here).

1:7 "In Hom het ons die verlossing deur sy bloed ..."

Implisiete paraklese: Vertrou op die verlossing deur Jesus

Christus (vgl. 6:17 - neem aan die helm van verlossing). 


\section{DIE BETEKENIS VIR DIE PREDIKING VANDAG}

\subsection{Die balans tussen indikatief en imperatief in die prediking}

In die Skrifgetroue prediking mag die fyn balans van indikatief en paraklese in die Efesiërbrief nie versteur word nie. Indien daar uit die eerste (indikatiewe) deel van die brief gepreek word, moet die band daarvan met die tweede (parakletiese) deel verdiskonteer word, en andersom.

Verder kan die fyn balans wat die Efesiërbrief tussen indikatief en paraklese vertoon, rigtinggewend wees vir die prediking oor die algemeen:

* Paraklese wat sonder indikatief gepreek word, is wortelloos en het geen vaste bodem nie;

- Indikatief wat sonder paraklese gepreek word, is soos 'n boom sonder vrugte.

* In die prediking mag die indikatief nie bloot maar ter wille van of selfs as kneg van die paraklese aangewend word nie, dit wil sê om daardeur aan die paraklese darem 'n bepaalde basis te verleen nie.

* Ook mag die paraklese nie maar as aanhangsel by die indikatief bygevoeg word "net om te wys dat die preek darem ook praktiese sake aanroer" nie.

Beide indikatief en paraklese is wesentlike deel van die prediking en moet as organiese geheel in fyn balans met mekaar gepreek word.

\subsection{Praktiese voorbeeld van indikatief-parakleseprediking uit Efesiērs}

Ter illustrasie van die samehang waarin die indikatief en paraklese van die Efesiërbrief gepreek behoort te word, word 'n teksvers uit die eerste briefdeel geneem, naamlik Efesiërs 2:10.

\section{Efesiërs 2:10}

"Want ons is sy maaksel, geskape in Christus Jesus tot goeie werke wat God voorberei het, sodat ons daarin kan wandel."

Hierdie vers verkondig primêr die indikatief oor dit wat God in Jesus Christus aan ons gedoen het:

" God het ons gemaak.

* God het ons in Christus Jesus geskape tot goeie werke.

* God het die goeie werke vir ons voorberei. 
Daarom sou die prediking van hierdie vers ook 'n hoofsaaklik indikatiewe strekking hê, met die hoofgedagte: God het ons in Jesus Christus tot 'n nuwe lewe van goeie werke herskep.

Ten einde hierdie indikatief noukeuriger uit te bou, behoort die sentrale lyne van die eerste briefdeel nagevolg te word. Die sentrale lyne wat 2:10 raak (vgl. skematiese uiteensetting 1), is dié van:

- die uitverkiesing (vgl. lyn a op die uiteensetting);

- heilig en sonder gebrek, goeie werke, heilige tempel (vgl. lyn b op die uiteensetting);

- die (her-)skepping (vgl. lyn r);

- die nuwe lewenswandel (vgl. lyn q).

Langs hierdie lyne kan die volgende sake as deel van die indikatief van die preek uitgebou word:

- Wat was die aanleiding tot ons herskepping?

Die uitverkiesende genade van God (vgl, in 1:4,5,6: God het ons in Christus uitverkies ... om heilig en sonder gebrek te wees; en 2:10: geskape in Christus tot goeie werke).

- Wat was die grond van ons herskepping? Jesus Christus (1:4 en 2: 10: "in Jesus Christus") as ons Verlosser (1:7) en as ons Hoof (1:22).

- Wat is die wese van ons herskepping? God het ons uit ons ou lewe laat oorgaan in 'n nuwe lewe (2:1-9).

- Wat was die doel van ons herskepping? Dat ons in goeie werke sal wandel (1:10), heilig en sonder gebrek (1:4).

- Waar kom die goeie werke vandaan?

God het dit voorberei. Dus: nie uit onsself nie $(2: 8,9)$, maar dit is vrug van die Gees in ons (5:9).

Die trinitariese motief tree sterk in bostaande na vore, en is, soos in 2.1.2.1 aangedui is, uiters belangrik in Efesiërs.

Implisiet is daar egter in die indikatief van 2:10 ook paraklese opgesluit. Op implisiete wyse word aangesluit by gedeeltes in die tweede (parakletiese) briefdeel. Die hoofsaak van die implisiete paraklese in 2:10 sou soos volg saamgevat kon word: Wandel in die goeie werke wat God voorberei het! 
In die prediking kan die paraklese van 2:10 dan verder verbesonder word deur by die tweede (parakletiese) briefdeel aan te sluit.

"Die woord "wandel" ( hierdie vers aan die latere paraklese van die brief te verbind. Praktiese voorbeelde van goeie werke waarin ons as nuwe skepsele moet wandel, kan dus met reg uit die "wandel"-gedeeltes van hoofstukke 4-6 gehaal word.

- Die paraklese van Efesiërs 4:24 skakel agter struktureel baie duidelik met 2:10 as gevolg van die werkwoord "geskape" ( $\mathrm{K} \tau \mathrm{i} \zeta \in \mathrm{LV}$ ), wat in beide dele voorkom. Op die patroon van 4:22-32 kan die preek dan 'n praktiese teenstelling bied tussen die werke van die ou mens en die goeie werke van die nuwe mens. Hierin sou aangeraak kon word:

- woordwerke: leuen versus waarheid (4:25);

- gesindheidswerke: toorn versus vergewingsgesindheid (4:26);

- daadwerke: diefstal versus eerlike arbeid (4:28);

- woordwerke: vuil praatjies versus woorde van stigting (4:29).

Indien die teksvers uit die paraklese-gedeelte gekies word, byvoorbeeld 4:24, sal die aksent van die preek weer op die paraklese val, en sal die paraklese begrond word in die indikatief wat hierbo aangedui is. Vir die praktyk van preekmaak uit die Efesiërbrief is die navolging van sentrale gedagtelyne, soos hierbo aangetoon, inderdaad baie nuttig.

\section{BIBLIOGRAFIE}

ABBOTT, T.K. 1946. A critical and exegetical commentary on the epistles to the Ephesians and the Colossians. Edinburgh : Clark. 315 p. (The International Critical Commentary.)

AUNE, D.E. 1987. The New Testament and its literary environment. Philadelphia : Westminster Press. $223 \mathrm{p}$.

BLASS, F. \& DEBRUNNER, A. 1975. A Greek grammar of the New Testament and other early Christian literature, translated by R.W. Funk. Chicago : University Press. 325p.

BERKELBACH VAN DER SPRENKEL, S.F.H.L. 1941. De kerk; de brief aan de Efezièrs. Nijkerk : Callenbach. $116 \mathrm{p}$. (De prediking van het Nieuwe Testament.)

CALVYN, J. 1979. Commentaries on the epistles of Paul to the Galatians and Ephesians, translated by W. Pringle. Grand Rapids : Baker. 398 p. (Calvin's Commentaries volume XXI.)

DE KLERK, B.J. 1988. Koninkryk, Gees en Woord in die gebed van Efesiërs 3:14-21. (In Coetzee, J.C., red. Koninkryk, Gees en Woord; huldigingsbundel aangebied aan prof. L. Floor. Pretoria : NG Kerkbockhandel. p.38-54.)

DOTY, W.G. 1973. Letters in Primitive Christianity. Philadelphia : Fortress Press. 84 p. 
DU PLESSIS, I.J. 1962. Christus as Hoof van kerk en kosmos. Groningen : Theologische academie. $148 \mathrm{p}$.

DU TOIT, A.B. 1984. Orienterende opmerkings oor die Pauliniese briefliteratuur. (In Du Toit, A.B., red. Handleiding by die Nuwe Testament; die Pauliniese briewe: Inleiding en Teologie. Pretoria : NG Kerkboekhandel. p.1-22.)

FISCHER, K.M. 1973. Tendenz und Absicht des Epheserbriefes. Göttingen : Vandenhoeck \& Ruprecht. $220 \mathrm{p}$.

FLOOR, L. 1982. Pcrspekticwe op dic prediking van Paulus. Pretoria : NG Kerkbockhandel. 111p.

GROSHEJDE, F.W. 1960. De brief van Paulus aan de Efeziërs. Kampen : Kok. 244 p. (Commentaar op het Nicuwe Tcstament.)

GUTHRIE, D. 1961. Ncw Testament intruduction; the Pauline epistles. London : Tyndalc press. $319 \mathrm{p}$.

HOULDEN, J.L. 1977. Paul's letters from prison. London : SCM Press. 357 p. (SCM Pelican commentaries.)

KüMMEL, W.G. 1972. Introduction to the New Testament. London : SCM Press. 444 p.

LOPES, A.N.G.P. 1986. The new man in Paul. Polchcfstroom. 123 p. (Verhandeling (Th.M.) P.U. vir C.H.O.)

LOUW, J.P. \& NIDA, A. red. 1988. Greck-English lexicon of the New Testament based on scmantic domains. 2 vols. New York: United Bible Societies.

MEYER, R.P. 1977. Kirche und Mission im Epheserbrief. Stullgart : Katolisches Bibelwerk. 85p. (Stuttgarter Bibelstudicn 86.)

ROBERTS, J.H. 1963. Die opbou van dic kerk volgens dic Efesebrief. Groningen : Theologische academic. $200 \mathrm{p}$.

ROBERTS, J.H. 1975. Die teologiese sentrum van die Corpus Paulinum. Theologia Evangelica, 8:1-22.

ROBERTS, J.H. 1983. Dic bricf aan die Efcsiërs. Kaapstad : NG Kerkuitgewers.

ROBERTS, J.H. 1984. Die gevangenskapsbriewc. (In Du Toit, A.B., red. Handleiding by die Nuwe Testament; die Paulinicse bricwe: Inleiding en teologic. Pretoria : NG Kerkboekhandel. p. 114-157.)

ROBERTS, J.H. 1986. Transitional techniques to the lelter body in the Corpus Paulinum. (In Petzer, J.H. \& Hartin, P.J. reds. A South African perspective on the New Testament. Leiden : Brill. p. 187-201.)

ROBERTS, J.H. 1988. Belydenisuitsprake as Pauliniese bricfoorgange. Henormde Teologiese Studies, 44(1):81-97.

VAN LEEUWEN, J.A.C. 1921. Paulus' zendbrieven aan Efeze, Colosse, Filémon, en Thessalonika. Amstcrdam : Van Bottenburg. 457 p. (Kommentaar op het Nieuwe Testament.)

VAN ROCN, A. 1974. The authenticity of Ephesians. Leiden : Brill. 449 p. (Supplements to Novum Testamentum.)

VAN ROON, A. 1976. De bricf van Paulus aan de Epheziërs. Nijkerk : Callenbach. 194 p. 